\title{
Effectiveness Of Mathematic Learning Media Based On Mobile Learning In Improving Student Learning Motivation
}

\author{
A.Muhajir Nasir ${ }^{1)}$, Nirfayanti ${ }^{2)}$ \\ ${ }^{1,2}$ Universitas Muslim Maros \\ *E-mail : amuhajirnasir@umma.ac.id
}

\begin{abstract}
This study aims to determine the effectiveness of the use of mobile learning based learning media on students' learning motivation in the Mathematics Education Study Program FKIP Maros Muslim University. The type of research used in this research was quantitative research with an experimental approach with the research subject being Mathematics Education Study Program students who are taking basic geometry courses in the even semester 2018/2019. The research design used was one group pretest-posttest design. Data was collected through tests and motivational questionnaires. The initial data analysis is used to check the normality of the data. The final analysis used the one sample t-test and normalized n-gain test. The results showed that the average normalized gain of student mathematics learning motivation was in the medium category and there was an increase in student learning motivation after being taught by applying the use of mobile learning in basic geometry learning.
\end{abstract}

Keywords: Learning Media; Mobile Learning; Learning Motivation

\section{INTRODUCTION}

The development of information and communication technology has brought enormous changes to the progress of the world of education. Along with these developments, learning methods have also undergone many developments, both personal learning methods, learning media or the learning process. The form of the development of information technology that is applied in the world of education is mobile learning. Mobile learning is an innovation that has a very large contribution to changes in the learning process, where the learning process no longer only listens to the material description of the lecturer but students also carry out other activities such as observing, doing, demonstrating and others. Teaching material material can be visualized in a variety of formats and forms that are more dynamic and interactive so that learners or students will be motivated to be further involved in the learning process. The Mathematics Education Study Program FKIP Muslim University of Maros, still applies conventional learning. Conventional learning referred to here is learning in which the delivery of material is described by lecturers with standard learning media, for example powerpoint or without learning media then giving questions (assignments) to students with limited material. During this time what happens in the field of students tends to be passive and only accepts the material that has been delivered by the lecturer and it is limited only on campus, as a result the process and student learning outcomes become less effective and have not achieved the specified goals. Furthermore, teaching materials that are generally used are good by lecturers and students is a conventional printed textbook that has not been able to increase student interest in learning, and is one of the causes of low student motivation. According to Kusuma (2011), the most important thing in the independent learning process is an increase in the willingness and skills of 
students in the learning process without the help of others, so they do not depend on lecturers, friends, or others in learning. The students' independence in implementing the learning process is a state of low student motivation which in turn will lead to a low understanding of students, especially in basic geometry courses. With this mobile learning media, it is hoped that it will make the learning process more conducive, increase student learning motivation, and can enhance the learning process of students in learning which in turn is expected to enhance the learning outcomes achieved

\section{RESEARCH METHOD}

This type of research is quantitative research with an experimental approach. This research is used to describe the effectiveness of mobile learning media learning in basic geometry courses in terms of 2 aspects namely the test of learning outcomes and student motivation. The research design used was One Group Pretest-Posttest Design using treatment of the research object by involving only one class group as an experimental class without control variables. The designs in this study can be seen in the following Table 1 :

Table 1. (One Group Pretest-Posttest Design)

\begin{tabular}{ccc} 
Pretest & Treatment & Posttes \\
\hline $\mathrm{O}_{1}$ & $\mathrm{X}$ & $\mathrm{O}_{2}$ \\
\hline
\end{tabular}

Information:

$\mathrm{X}$ : Learning by using mobile learning

O1: Pre-test before learning

O2: The final test (posttes) after learning

This research was conducted in the even semester of the 2018/2019 school year at the Muslim University of Maros, which is located at J1.Dr.Ratulangi No.62 Maros. The research subjects were even semester students of the Mathematics Education Study Program FKIP Muslim University of Maros, amounting to 16 people and were taking basic geometry courses in the 2018/2019 school year. The data collection techniques used are first, the student learning achievement test which has been validated by experts and has been tested empirically and calculated its reliability with a reliability coefficient of 0.80 . Second, the student learning motivation questionnaire that has been validated by experts and has been empirically tested for its reliability with a reliability score of 0.90 .

Data analysis techniques used in this study are descriptive and inferential analysis. Data about student learning outcomes were analyzed descriptively. Descriptive learning outcomes data are spelled out in the frequency distribution table so students will see certain scores. The criteria used to determine the categories of basic geometric learning outcomes in this study refer to the scale compiled by the Ministry of National Education in (Nirfayanti; Dedy Setyawan, 2018) as in Table 2 below 
Table 2. Basic Geometry Learning Outcomes Criteria

\begin{tabular}{cc}
\hline Tingkat Penguasaan & Kategori \\
\hline $90-100$ & Very High \\
$80-89$ & High \\
$65-79$ & Middle \\
$55-64$ & Low \\
$0-54$ & Very Low \\
\hline
\end{tabular}

If students have a moderate level of mastery, then students fall into the category of complete learning. In addition, learning is said to be effective if it meets the criteria of at least $85 \%$ of students having a level of mastery of the material or at least at a moderate level.

Selain mendekripsikan hasil belajar mahasiswa, dalam penelitian ini akan dideskripsikan bagaimana perbedaan motivasi belajar mahasiswa yang terjadi sesudah mahasiswa diberikan perlakuan. Perbedaan tersebut akan ditinjau berdasarkan perhitungan nilai gain ternormalisasi dan menentukan kategorinya sesuai dengan tabel 3 berikut ini.

Table 3. Normalized Gain Category

\begin{tabular}{cc}
\hline Interval & Kategori \\
\hline$<\mathrm{g}>\geq 0,70$ & High \\
$0,30<<\mathrm{g}><0,70$ & Middle \\
$<\mathrm{g}>\leq 0,30$ & Low
\end{tabular}

Furthermore, student learning motivation data will be analyzed inferentially to find out whether or not there is an increase in student motivation in the use of mobile learning media by using the one sample t-test using SPSS 16 for windows software.

\section{RESULT AND DISCUSSION}

In this study, student learning outcomes are obtained from students after carrying out mobile learning learning. The learning achievement test was attended by 16 students of mathematics education FKIP Muslim University of Maros.

Table 4. Recapitulation of Student Learning Outcomes Tests

\begin{tabular}{lc}
\hline & Posttest \\
\hline Ukuran Subjek & 16 \\
Nilai Terendah & 85 \\
Nilai Tertinggi & 95 \\
Mean & 92,50 \\
Median & 95 \\
Modus & 95 \\
Standar Deviasi & 4,472 \\
\hline
\end{tabular}

The results showed that the test scores of student learning outcomes on material geometric elements after being applied to mobile learning were quite varied. The lowest score of the Student Learning Outcomes Test (THBM) of 85 and the highest score obtained by students of 95. Many students who have completed the material on these geometric elements as many as 16 people (or $100 \%$ complete). Meanwhile, the average value of student learning outcomes after applying mobile learning learning is 92.50 or in the very high category. Therefore 
learning basic geometry using mobile learning is said to be effective because it meets the criteria of at least $85 \%$ of students having a level of mastery of the material or at least at a moderate level. After the student is given the final test, the next step is to give a learning motivation questionnaire.

Table 5. Recapitulation of Student Learning Motivation

\begin{tabular}{lcc} 
& Pretest & Posttest \\
\hline Ukuran Subjek & 16 & 16 \\
Nilai Terendah & 52 & 72 \\
Nilai Tertinggi & 71 & 96 \\
Mean & 60,50 & 84,44 \\
Median & 60 & 85 \\
Modus & 53 & 94 \\
Standar Deviasi & 5,808 & 9,063 \\
\hline
\end{tabular}

In Table 5 it can be seen that the scores of students' learning motivation after being taught with the use of mobile learning experience positive changes. Based on the description of student motivation to learn above, the motivation to learn mathematics students after being taught by using mobile learning in the experimental class in this study can be said to increase.

Table 6. Normalized Gain of Student Learning Motivation

\begin{tabular}{lccccc} 
& Min & Max & Mean & Varians & $\begin{array}{c}\text { Standar } \\
\text { Deviasi }\end{array}$ \\
\hline $\begin{array}{l}\text { Skor Gain } \\
\text { Ternormalisasi }\end{array}$ & 0,341 & 0,892 & 0,608 & 0,048 & 0,218 \\
\hline
\end{tabular}

Table 6 shows that the average normalized gain of students' motivation to learn mathematics is 0.608 . Based on the normalized gain category in table 3 , the score is in the medium criteria. That is, classically the motivation to learn mathematics students in basic geometry courses after being taught by using mobile learning has a moderate increase. The data that has been collected beforehand is tested for normality to find out whether the data obtained is normally distributed or not.

Table 7. Research Data Normality Test Results

\begin{tabular}{lcccc}
\hline Sumber & Nilai- $p$ & $\alpha$ & Keputusan & Kesimpulan \\
\hline $\begin{array}{l}\text { Gain Ternormalisasi } \\
\text { Motivasi Belajar }\end{array}$ & 0,668 & 0,05 & Nilai- $p>\alpha$ & Normal \\
\hline
\end{tabular}

Based on the results of the normality test above, the p-value obtained in the Kolmogorov-Smirnov test is more than 0.05. Because the p-value (sig) is more than 0.05 , it can be concluded that the data in this study come from populations that are normally distributed. With the fulfillment of data normality prerequisite tests, then in testing the research hypothesis can be done by t-test. 
Tabel 8. Hasil Uji One Sample t-Test

\begin{tabular}{lccc}
\hline Sumber & $t$ hitung & Nilai- $p$ & Keputusan \\
\hline $\begin{array}{l}\text { Gain Ternormalisasi } \\
\text { Motivasi Belajar }\end{array}$ & 5,660 & 0,000 & Ho ditolak \\
\hline
\end{tabular}

$\mathrm{H}_{0}$ : There is no increase in student motivation after being taught by applying the use of mobile learning in learning basic geometry

Based on the summary of the results of data analysis in table 8 , the value of tcount $=5.660$ with $\mathrm{p}$-value $=0.000<\alpha=0.05$. Because the $\mathrm{p}$-value $<0.05$, according to the decision criteria for hypothesis testing, it can be concluded that Ho is rejected. That is, there is an increase in student motivation after being taught by applying the use of mobile learning in learning basic geometry.

From the results of student learning motivation questionnaires, students generally gave positive evaluations of mobile learning. This is shown from $85.94 \%$ of students giving positive responses to the implementation of learning using mobile learning, $92.19 \%$ of students stated that mobile learning has an attractive appearance and complete material, and $84.38 \%$ of students feel motivated, better understand geometry material basic, and helped with mobile learning. The data shows that $100 \%$ or all questions responded positively by more than $80 \%$ of students, this indicates that the learning that was carried out was effective. This is in line with the criteria of effective learning, that is, if the student's response to learning is at least $70 \%$ of all questions responded positively by at least $50 \%$ of students (Nurdin, 2007).

The learning culture developed in the experimental class is the activeness of students in developing their own curiosity, and the use of time that can be optimal because their learning activities do not recognize space and time, according to the opinion of El-Hussen and Cronje (2010) states that mobile learning as a learning model in the environment learning that contains technological mobility, students, and learning. spread quickly and is likely to be one of the most efficient ways of providing higher learning in the future.

Thus, the activeness of students in building their own knowledge is expected to help students to be motivated in understanding the subject matter. Students can freely operate the media used to stimulate memory and the ability to understand the material in gnomio-based mobile learning applications. In addition to the increased level of student learning motivation, other strengths that support effective gnomio-based mobile learning applications are shown from several indicators in the learning process, including students starting to dare to ask material that is not yet understood to lecturers / friends so that they are able to solve practice questions independently and present it to the class. This is in line with Kusuma's opinion (2011: 49), that independent learning does not mean selfstudy. The most important thing in the independent learning process is an increase in the willingness and skills of students in the learning process without the help of others, so they do not depend on lecturers, friends, or others in learning.

The research data above is in line with research conducted by Hernawan (2017) entitled "Use of HTML 5-Based Mobile Learning Applications to Improve Students' Understanding in Microbiology Courses" that the use of HTML5-based mobile learning applications results in an increase in student understanding that is 
higher than the media conventional. On the other hand, mobile learning intended in this study is gnomio-based mobile learning, while the research conducted by (Hernawan, 2017) is HTML 5 based mobile learning. Although the results of both studies are the same which says that mobile learning is higher than conventional media but there are still differences. Likewise with the results of research conducted by (Nirfayanti; Dedy Setyawan, 2018) that through the use of computer applications in learning will make students more active and understand the material provided compared to without using learning media based on information and communication technology.

\section{CONCLUSION AND SUGGESTION Conclusion}

Based on the results of research and discussion that has been stated, it can be concluded that there is an increase in student motivation after being taught by applying the use of mobile learning in learning basic geometry. Students are very happy to learn the material contained in the gnomio-based mobile learning application because it looks interesting and is able to build their own knowledge because through this application students are directed to independent learning. The results of data analysis also showed that the average normalized gain of students' mathematics learning motivation before and after being taught mobile learning had a moderate increase.

\section{Suggestion}

It is expected that research like this is also carried out on other lecture material, especially in mathematics education study programs, making students interested, happy, and actively learning mathematics to find suitable models, methods and media in order to increase students' motivation to learn mathematics on certain subjects.

\section{REFFERENCES}

Dai, D. Y., \& Sternberg, R. J. (2004). Motivation, emotion, and cognition: Integrative perspectives on intellectual functioning and development. Routledge.

EL-Hussein, M. and Cronje, J. (2010). Defining Mobile Learning in the Higher Education Landcape. Education Technology \& Society, 13 (3), 12-1.

Hernawan, H. (2017). PENGGUNAAN APLIKASI MOBILE LEARNING BERBASIS HTML 5 UNTUK MENINGKATKAN PEMAHAMAN MAHASISWA PADA MATA. Pedagogia: Jurnal Ilmu Pendidikan, 645652.

Kusuma, Ade. (2011). E-Learning dalam Pembelajaran. Lentera Pendidikan, 14 (1), 35-51.

Nasir, A. M., Upu, H., \& Ihsan, H. (2016). PENERAPAN MEDIA ANIMASI PADA MATERI BANGUN DATAR SEGIEMPAT DALAM PEMBELAJARAN MATEMATIKA KELAS VII SMP. Jurnal Ecosystem, 16(3), 477-488. 
Nirfayanti, N., \& Setyawan, D. (2018). EFEKTIFITAS PEMBELAJARAN PROGRAM LINEAR BERBANTUAN GEOGEBRA TERHADAP HASIL BELAJAR MAHASISWA. Proximal: Jurnal Penelitian Matematika dan Pendidikan Matematika, 1(2).

Nurdin. (2007). Model Pembelajaran Matematika yang Menumbuhkan Kemampuan Metakognitif untuk Menguasai Bahan Ajar. Disertasi tidak diterbitkan.

Setyawati, Rina Dwi, dkk. (2017). Efektivitas Model Problem Based Learning Berbantuan Mobile Learning Pada Mata Kuliah Matematika Ekonomi. LPPM Universitas PGRI Semarang. Diakses pada https://eprints.upgris.ac.id pada tanggal 6 Oktober 2018

Uno, Hamzah B. (2008). Teori Motivasi dan Pengukurannya. Jakarta: Bumi Aksara 